\title{
PODER E DECADÊNCIA EM SÃO BERNARDO, LA CASA DE LOS ESPÍRITUS E O MANUAL DOS INQUISIDORES
}

\author{
PODER Y DECADENCIA EN SÃO BERNARDO, LA CASA \\ DE LOS ESPÍRITUS Y O MANUAL DOS INQUISIDORES
}

\author{
Josiane Aparecida Franzó*
}

Resumo: O objetivo deste estudo é fazer uma comparação entre os romances São Bernardo, La casa de los espíritus e O manual dos inquisidores tendo como foco principal os personagens masculinos: suas posições de poder, muito bem representadas em suas propriedades; a necessidade da total apropriação da mulher, suas esposas; a impossibilidade desta apropriação e, consequentemente, a decadência psicológica, física e moral desses indivíduos. A comparação aqui proposta leva em consideração o contexto histórico em que estes personagens estão inseridos: golpes militares e mudanças do cenário político e econômico, bem como o papel fundamental que as mulheres exercem sobre seus esposos, funcionando mesmo como ativadoras do processo de transformação deles.

Palavras-chave: Homem. Poder. Mulher. Decadência.

Resumen: El objetivo de este estudio es hacer una comparación entre las novelas de San Bernardo, La casa de los espíritus y El manual de los inquisidores teniendo como enfoque principal los personajes masculinos: sus posiciones de poder, muy bien representadas en sus propiedades; la necesidad de total apropiación de la mujer, sus esposas; la imposibilidad de esta apropiación y por lo tanto, la decadencia psicológica, física y moral de estos individuos. La comparación que aquí se propone tiene en cuenta el contexto histórico en que estos personajes se introducen: los golpes militares y los cambios de la escena política y económica, así como, el papel crucial que las mujeres tienen sobre sus maridos, actuando mismo como activadoras del proceso de transformación de ellos.

Palabras-clave: Hombre. Poder. Mujer. Decadencia.

\footnotetext{
* Doutoranda em Teoria Literária no Programa de Pós-Graduação em Literatura da Universidade Federal de Santa Catarina. E-mail: <josianefranzo@hotmail.com>.
} 
Em geral, quando nos deparamos com uma obra literária que aborda fatos históricos, nós, leitores, temos a tendência de procurar compreender esta obra como registro real de determinada época, não separando muito bem o limite entre ficção e realidade, esquecendo que a literatura é a tentativa de reprodução do real de acontecimentos resgatados pela memória.

Mikhail Bakhtin (1997, p.211), em sua obra Estética da criação verbal, defende que quando se tende exclusivamente a reconhecer, quando se busca unicamente o conhecido (o que já ocorreu), impede-se a revelação do novo, daquilo que constitui o essencial, o conjunto irreproduzível. Conforme Bakhtin (1997, p.211), a pessoa aproxima-se da obra com uma visão do mundo já formada, a partir de um dado ponto de vista. Ainda segundo o autor, esta situação em certa medida determina o juízo sobre a obra, mas nem por isso permanece inalterada: ela é submetida à ação da obra que sempre introduz algo novo, pois uma obra, poderosa e profunda, é, sob muitos aspectos, inconsciente e portadora de sentidos múltiplos (idem, p.211).

Sobre a posição do leitor diante de uma obra, Jean-Paul Sartre (1994, p.64) considera que:

[...] a verdadeira relação do leitor com o autor continua sendo o não-saber; ao ler o livro, o leitor deve ser levado indiretamente a sua própria realidade de singular universal; ele deve se realizar - não só porque entra no livro, mas porque nele não entra totalmente - como uma outra parte do mesmo todo, como uma outra visão do mundo sobre ele mesmo (grifos nossos).
Em relação ao produto acabado, ou seja, a criação, Walter Benjamin (1994) irá dizer que articular historicamente o passado não significa conhecê-lo como ele foi de fato, mas significa apropriar-se de uma reminiscência. Tal ideia é avalizada por Márcio Seligmann-Silva (2005) que diz que a literatura encena a criação do "real". Embora nesta encenação as palavras nem sempre deem conta do real, do vivido, como bem expressou Lobo Antunes ${ }^{1}$ em entrevista: " $E$ depois aquilo que a gente sente é tão mais forte que as palavras...". Contudo, a literatura faz parte da história e, como parte desta, está carregada de elementos daquele momento. Cabe ao escritor, enquanto artesão (nos termos de Sartre), reorganizar estes elementos e transpô-los para sua criação. Neste sentido, partindo da visão de que o escritor, em sua obra, de modo acidental ou proposital, depõe sempre sobre sua época, propomo-nos a estabelecer uma comparação entre São Bernardo, de Graciliano Ramos, publicado em 1933, La casa de los espíritus, de Isabel Allende, publicado em 1982, e O manual dos inquisidores, de António Lobo Antunes, publicado em 1996. Escritos em épocas diferentes, em países diferentes - Brasil, Chile e Portugal respectivamente, esses romances trazem como pano de fundo, ainda que não se perca o foco de que são ficções, recortes da vida, do governo vigente, da sociedade, enfim, do contexto histórico em um determinado momento de cada um desses países.

Vale a pena ressaltar que os criadores destes romances tiveram, cada qual de um

1 Disponível em: <http:/www.ala.nletras.com/citario/ politica.htm>. Acesso em: 10 ago. 2010. 
modo particular, contato direto com as ditaduras retratadas em suas obras, bem como com o que se estabeleceu depois delas. Graciliano Ramos, sensível aos problemas sociais, consciente do seu papel enquanto homem das letras, filia-se ao Partido Comunista e acaba sendo preso pelos militares ${ }^{2}$. Isabel Allende, como parenta direta do presidente Salvador Allende, assassinado no Chile, é obrigada a abandonar o país, e será a partir deste exílio que irá compor a obra aqui referida. E Lobo Antunes, que em entrevista expressou que é preciso muito sofrimento para escrever bem - para tocar os outros -, e que queria que cada página de sua obra fosse um espelho - para o leitor, serviu em Angola no período ditatorial, e anos mais tarde torna-se militante da Aliança Povo Unido - APU, por um curto período de tempo ${ }^{3}$.

Desse modo, tendo ciência de que em algum momento da vida destes escritores, eles foram testemunhas oculares das mudanças políticas ocorridas em seus países $e$, ainda que em recortes, levaram para suas obras fatos da realidade 4 , não se pode deixar

\footnotetext{
2 Para exemplo meramente ilustrativo citamos fragmentos de Auto-retrato aos 56 anos, onde Graciliano assim se define (em terceira pessoa): "É ateu", "Odeia a burguesia", "Deseja a morte do capitalismo", "Apesar de o acharem pessimista, discorda de tudo", "Esteve preso duas vezes. É lhe indiferente estar preso ou solto".

3 Em entrevista no ano de 1997, Lobo Antunes assim explica seu desligamento do partido: "A forte hierarquia, a ausência de debate aberto e alargado, isso assusta-me um bocado". Disponível em: <http://www.ala.nletras. com/citario/politica.htm>. Acesso em: 10 ago. 2010.

4 Seligmann-Silva assim discorre sobre a literatura de testemunho: "Na qualidade de produto do intelecto, seu testemunho está inscrito na própria linguagem, no uso que faz dela, no modo como através de uma intrincada tecedura ela amarra o 'real', a imaginação, os conceitos e o simbólico”. (SELIGMANN-SILVA, 2005, p.76).
}

de refletir sobre a semelhança temática que permeia os três romances: o poder concentrado na figura de um indivíduo, os golpes militares, a opressão aos desfavorecidos, a tentativa de posse da mulher amada e a decadência financeira, física e moral.

Estes romances têm em comum a figura masculina como personagem principal, sua propriedade como reflexo de seu poder e a fragilidade diante de mulheres, que foram amadas, porém, incompreendidas por eles.

Há entre os três personagens uma força motriz natural que os torna opressores das classes menos favorecidas, de todas as formas possíveis. São três patriarcas, representações do poder, que fazem o que bem entendem com tudo e todos, agindo como se pessoas não passassem de meros objetos de uso: "encolhida de medo por ser o patrão, por ser rico, por ser ministro ou assim, por mandar em muita gente em Lisboa [...]" (ANTUNES, s/d, p.17).

Dos três romances, São Bernardo é o único que tem apenas um narrador, o próprio Paulo Honório, que nos relata toda a sua trajetória - de menino pobre a grande latifundiário. Com pais desconhecidos, não mencionados em sua certidão de nascimento, e sendo, como ele próprio anuncia no início de sua narração, o "iniciador de uma família", o que para ele não deixa de ser um bônus, pois o livrou "da maçada de suportar parentes pobres” (RAMOS, 1983, p.12).

Paulo Honório, ainda jovem, decide ganhar dinheiro, mas "o capital se desviava" dele e depois de muita penúria, determinação e coragem: "sofri sede e fome, dormi na areia dos rios secos, briguei com gente que fala aos berros e efetuei transações 
comerciais de armas engatilhadas" (idem, p.14), consegue enganar o filho do antigo patrão e obter a fazenda São Bernardo. Com todos os esforços possíveis reconstrói a propriedade. Adepto das novidades tecnológicas de plantio, adquire máquinas modernas, emprestando dinheiro do banco e ganhando várias causas no fórum graças ao seu advogado. Além disso, maneja os vários poderes ao seu redor: padre, capanga, advogado, jornalista, passando por cima de tudo com um único propósito: o ganho. Tudo e todos são para Paulo Honório apenas objetos de lucro, ou intermediários para este fim.

Esteban tem uma caminhada parecida com a de Paulo Honório. De sobrenome nobre por parte de mãe, mas com infância pobre, decide, depois de ganhar algum dinheiro nas minas onde: "Trabajaba como um animal y las pocas veces que me sentaba a descansar, obligado por el tedio de algún domingo, sentía que estaba perdiendo momentos preciosos [...]" (ALLENDE, 2001, p.31), recuperar a fazenda em ruína que pertencera a sua família: "Para sacar a Las Tres Marías de la miseria destiné todo el capital que habiá ahorrado [...]", "pero no fue el dinero el que salvó a esa tierra, sino el trabajo y la organización" (idem, p.63). Esteban torna-se um latifundiário rico, poderoso, cruel e reacionário, transformando Las Tres Marías em uma potência, tanto que "en el transcurso de los diez años siguientes, Esteban Trueba se convirtió en el patrón más respetado de la región, construyó casas de ladrillo para sus trabajadores, consiguió un maestro para la escuela y subió el nivel de vida de todo el mundo en sus tierras (idem, p.73-74). Embora seu braço direito na fazenda insistisse em lhe dizer que não seriam estas casas ou algum alimento que o tornaria um bom patrão, e sim um salário digno pelo trabalho recebido.

Já de Francisco se sabe que é proprietário da Quinta Palmela, ministro do governo de Salazar e com grande influência sobre todos os poderes da sociedade portuguesa: "o retrato do senhor cardeal com o senhor doutor, o retrato do almirante com o senhor doutor, o retrato do professor Salazar com o senhor doutor, o retrato do Papa com o senhor doutor [...]" (ANTUNES, s/d, p.30). Francisco era tão influente que não tirava o chapéu nem para Salazar: "que nem para ele tirava o chapéu da cabeça nem deixava de fumar [...]" (idem, p.30).

Os três protagonistas, independentemente da origem de sua classe social, apresentam um caráter selvagem, autoritário e ao mesmo tempo solitário. No caso de Francisco e Esteban Trueba, o lado animal de seu apetite sexual predomina e o modo de aplacar esta selvageria é estuprando as filhas dos empregados das suas propriedades:

Esteban nosequitóla ropa. Laacometió con fiereza incrustándose en ella sin preámbulos, con una brutalidad inútil. Se dio cuenta demasiado tarde, por las salpicaduras sangrientas en su vestido, que la joven era virgen, pero ni la humilde condición de Pancha, ni las apremiantes exigencias de su apetito, le permitieron tener contemplaciones. Pancha García no se defendió, no se quejó, no cerró los ojos. Se quedó de espaldas, mirando el cielo con expresión despavorida, 
hasta que sintió que el hombre se desplomaba con un gemido a su lado. Entonces empezó a llorar suavemente. Antes que ella su madre, y antes que su madre su abuela, habían sufrido el mismo destino de perra. (ALLENDE, 2001, p.68). [...]

No pasaba ninguna muchacha de la pubertad a la edad adulta sin que la hiciera probar el bosque, la orilla del río o la cama de fierro forjado. Cuando no quedaron mujeres disponibles en Las Tres Marías, se dedicó a perseguir a las de otras haciendas, violándolas en un abrir y cerrar de ojos, en cualquier lugar del campo, generalmente al atardecer. No se preocupaba de hacerlo a escondidas, porque no le temía a nadie. (idem, p.74).

Francisco, após ser rejeitado e abandonado por Isabel - a quem amava muito passa a sentir uma grande necessidade de autoafirmação, por isso, além de violentar a filha do empregado, começa a manter relações sexuais com mulheres de várias camadas sociais - de sua cozinheira até a viúva do farmacêutico:

O meu pai de mão aberta na nuca da filha do caseiro, uma adolescente descalça, suja, ruiva, suspensa das tetas das vacas acocorada num banquinho de pau, a filar-lhe o cachaço e a obrigá-la a dobrar-se para a manjedoura sem largar os baldes do leite, o meu pai outra vez escarlate a esmagar-lhe $o$ umbigo nas nádegas, de cigarrilha acesa apontada às vigas do tecto sem que a filha do caseiro protestasse, sem que ninguém protestasse ou imaginasse protestar, o meu pai tirando a mão da minha nuca e designando com desprezo a cozinha, os quartos das criadas, o pomar, a quinta inteira, o mundo [...]. (ANTUNES, s/d, p.o3). [...]

[...] o senhor doutor de cinto desapertado, de colete aberto, prendendo-me a cintura com as coxas, a rir-se soprando-me o fumo da cigarrilha na nuca - Quietinha rapariga eu assustada pelo meu sangue a pingar nas estrias do cimento, pela ebulição das vacas, pelos guinchos do moinho a trambulhar a sul, a querer pedir ao senhor sem ser capaz de pedir - Jure que não me corta a garganta não me corte a garganta por favor não me corte a garganta [...]. (idem, p.40-41).

Todavia, independente de que mulher esteja ao seu lado, em todos os seus atos não deixa de afirmar sua posição de senhor: "Faço tudo o que elas querem mas nunca tiro o chapéu da cabeça para que se saiba quem é o patrão" (idem, p.13).

Paulo Honório, antes de sentir amor por Madalena, ainda que tenha mantido relações com outras mulheres, não tinha estes ímpetos descritos acima e sua única preocupação era providenciar um herdeiro:

Amanheci um dia pensando em casar. Foi uma ideia que me veio sem que nenhum rabo-de-saia a provocasse. Não me ocupo com amores, devem ter notado, e sempre me pareceu que mulher é um bicho esquisito, difícil de governar.

A que eu conhecia era a Rosa do Marciano, muito ordinária. Havia conhecido também a Germana e outras dessa laia. Por elas eu julgava todas. Não me 
sentia, pois, inclinado para nenhuma mulher: o que sentia era desejo de preparar um herdeiro para as terras de S. Bernardo. (RAMOS, 1983, p.59, grifo nosso).

Seu plano é tão racional que, dentre os três personagens, é o único que não tem filhos bastardos. Filho bastardo significa partilha de posses, e este risco definitivamente Paulo Honório não estava disposto a correr.

Embora façam e desfaçam das mulheres que cruzam seus caminhos, usando de todo seu poder como "senhor da casa grande", Paulo Honório, Esteban e Francisco - ainda que este passe a ter essas atitudes somente depois de Isabel traí-lo e deixá-lo - encontram na figura de suas esposas a impossibilidade de dominação. Pode-se dizer que, por conta disso, os papéis delas são fundamentais para o processo de autodesvelamento pelo qual os respectivos personagens-narradores passam em relação ao conhecimento de si próprios. Ou, dizendo de outro modo, são três narrativas em que os protagonistas masculinos vivem um processo de crise existencial e de identidade, e elas (Madalena, Clara e Isabel) são essenciais para provocar o início e a evolução desse processo psicomoral em cada um deles.

É pela ação, ideias e sentimentos, pelo modo de ser e pelos questionamentos delas que cada protagonista masculino acaba passando por um processo de transformação. Basta observar como eles são no início do relacionamento, o conflito existencial pelo qual passam e como se encontram depois da ausência delas. E é após a morte ou abandono de cada uma dessas mulheres que seus respectivos pares entram num processo catártico. Pode-se dizer que a decadência dos três personagens começa exatamente a partir da ausência delas. Tal função fundamental das mulheres projeta-se na própria estrutura do enredo de São Bernardo e de La casa de los espíritus, já que a partir de sua entrada bem como de sua saída, a estrutura global do enredo disso fica dependente. $\mathrm{Ou}$ seja, a estrutura da narrativa se organiza em função (ou em grande parte) da presença/ ação de cada uma dessas mulheres ${ }^{5}$. Em São Bernardo isso é colocado de forma bem explícita. A partir do momento em que Paulo Honório conhece Madalena, a fazenda passa a um segundo plano. Segundo João Luís Lafetá (1983), com a entrada de Madalena em cena, todos os motivos temáticos - manobras, negócios, brigas - convergem e encontram sua unidade no novo fito de Paulo Honório: a posse da mulher.

A princípio, Madalena reluta em casar, mesmo assim, diante da pressão de Paulo Honório, ela sucumbe, contrai matrimônio sem amor e acaba prisioneira de um tirano.

Como militante dos trabalhadores miseráveis da fazenda, Madalena enfrenta um senhor de posses, seu próprio marido, tenta derrubar a barreira de classe e de poder que está instalada em São Bernardo, e com seu amor ao próximo, desestrutura o mundo capitalista de Paulo Honório, que diz, por exemplo que: "[...] Essa gente faz o que se

5 Ainda que Isabel seja retomada pelos diversos narradores do romance (havendo momentos em que também "fala/narra"), é inegável que seu papel seja fundamental para a transformação ocorrida com o personagem principal. Todavia, será complexo falar que o enredo esteja estruturado em função dela, uma vez que esta ficção possui uma estrutura fragmentada. 
manda, mas não vai sem pancada. E Marciano não é propriamente um homem". (RAMOS, 1983, p.110). Ou seja, ela uma humanitária em potencial e ele um explorador de mão de obra que não considera o empregado como ser humano, mas sim como bicho: "Havia bichos domésticos, como o Padilha, bicho do mato, como o Casimiro Lopes, e muitos bichos para o serviço do campo, bois mansos" (idem, p.182, grifos nossos).

Helmut Feldmann (1998) diz que em São Bernardo, onde se exterioriza toda a autoexpansão e afirmação incondicionais de Paulo Honório, qualquer forma de altruísmo atua como dinamite. Assim, Madalena, com sua compaixão espontânea pela infelicidade dos pobres, começa a minar os fundamentos de São Bernardo.

Paulo Honório aos poucos vai entendendo que sua mulher se torna o adversário mais perigoso da sua obra: "Misturei tudo ao materialismo e ao comunismo de Madalena" (idem, p.132), e, por conseguinte, da sua pessoa: "Eu construindo e ela desmanchando".

Mas o que está sendo desmanchado por Madalena? A ordem na propriedade? Um sistema já instaurado e consolidado.

"Conheci que Madalena era boa em demasia [...]" (idem, p.101), ela é exatamente o oposto do esposo. É culta, solidária, generosa, comunista, intelectual, sensível aos problemas alheios, adepta de mudanças e inconformada com o sistema vigente. Por tudo isso, interfere na rotina de exploração e domínio perpetuada pelo esposo.

Podemos acreditar que, em verdade, Paulo Honório não sabe como lidar com os sentimentos que a companheira desperta nele. Um homem rude, racional e extremamente egoísta e que se vê de repente num dilema entre Madalena e São Bernardo, entre o amor desapegado e o sentimento de propriedade.

Acerca deste dilema, FELDMANN (1998) afirma que Paulo Honório não consegue abandonar a sua gaiola dourada de São Bernardo e entranhar-se no mundo de sua esposa, tão diversamente estruturado: "Conhecia nada! Era justamente o que me tirava o apetite. Viver com uma pessoa na mesma casa, comendo na mesma mesa, dormindo na mesma cama, e perceber ao cabo de anos que ela é uma estranha!" (idem, p.148).

Esta talvez tenha sido a maior angústia de Paulo Honório - não ter conseguido penetrar no mundo de Madalena, não tê-la compreendido em vida. Seu altruísmo, seu desapego a bens materiais, sua sensibilidade, tudo lhe fugiu à compreensão. Incompreensão que LAFETÁ (1983, p.204) descreve assim:

[...] Paulo Honório: egoísta e brutal. Não consegue compreender a mulher, pois é incapaz de senti-la em sua integridade humana e em sua liberdade, e a considera apenas como mais uma coisa a ser possuída.

Somente após a morte de sua amada e da solidão que se instalou em São Bernardo, é que Paulo Honório reflete sobre sua vida e a consequência de seus atos, e percebe o quão errado agiu em relação a Madalena e a sua própria vida:

Madalena entrou aqui cheia de bons sentimentos e bons propósitos. Os 
sentimentos e os propósitos esbarraram com a minha brutalidade e o meu egoísmo. (RAMOS, 1983, p.187). [...]

Foi este modo de vida que me inutilizou. Sou um aleijado. Devo ter um coração miúdo, lacunas no cérebro, nervos diferentes dos nervos dos outros homens. E um nariz enorme, uma boca enorme, dedos enormes.

Se Madalena me via assim, com certeza me achava extraordinariamente feio. (ibidem).

Do mesmo modo, Esteban não consegue trazer Clara para seu mundo, violento, capitalista e fechado. É preciso dizer que, apesar de conviverem anos e anos juntos, ela sempre esteve num mundo à parte, ajudando os camponeses, socorrendo os necessitados, abrigando os desconhecidos.

Quanto mais Clara se doava para as pessoas ao seu redor, mais Esteban sentia a necessidade de possuir sua atenção. O desejo de posse e ciúme de Esteban chega ao ponto de odiar seus filhos e expulsar sua irmã Férula por sentir neles um obstáculo entre ele e Clara: "Cada obstáculo que su hermana atravesaba entre Clara y él, lo ponía fuera de sí. Llegó a detestar a sus propios hijos porque absorbían la atención de la madre [...]" (ALLENDE, 2001, p.142). Porém, ainda que tente isolá-la, para que assim pudesse tê-la totalmente, cada passo que dá em direção a ela, cada atitude para afastá-la de outros acaba por ampliar o distanciamento que já se anunciava entre eles: "Mientras más distante estaba Clara, más grande era la necesidad que yo sentía de su amor" (idem, p.190). Depois da partida de Férula, que morre em seguida, e frequentes ausências de seus filhos, nada muda. Clara continua no seu mundo, no seu silêncio.

Já Isabel, esposa de Francisco, não tinha este lado altruísta. $O$ que a move a desistir de uma vida de luxo, prestígio e até mesmo de seu filho pequeno, é a constante carência do esposo que, com sua necessidade a cercava de todos os modos: “- Não me deixas em paz nem um momento Francisco?” (ANTUNES, s/d, p.101). O esposo, sem entender, ou até mesmo perceber sua situação, seu desejo de liberdade, passa a interrogá-la constantemente: "gostas de mim não gostas Isabel"? (idem, p.291), e "a senhora a fitá-lo e a desinteressar-se dele" (idem, p.103). Sentindo-se prisioneira, incapaz de sustentar por mais tempo o casamento, foge com alguém inferior à figura do marido, e na sequência passa a viver modestamente, porém com o que sempre desejou: "foi para ficar sozinha, longe deles, da sua angústia e da sua pressa, da sua ansiedade de antes e do seu desprezo de depois [...]" (idem, p. 349). Por esta opção de viver em liberdade ${ }^{6}$, Isabel transgride os padrões determinados para mulheres de sua classe social e da sua posição-a de esposa de ministro.

Este sentimento de se libertar daquela vida aparentemente tão bem estruturada, protótipo de família feliz, e do seu marido carente, persiste mesmo depois desta ter

\footnotetext{
6 Nos trechos a seguir percebemos o drama de uma mulher que sente o desejo de se libertar do fardo de ter que viver uma vida a dois: "eu que não pedira, que na queria nada, a quem não apetecia nada salvo estar sozinha sem homens a perseguirem-me com os seus interrogatórios sem sentido" - "sozinha sem o peso insuportável de acharem que gostavam de mim, me acordarem no meio da noite sobressaltando-me com perguntas" - "onde não me inquietavam, não me aborreciam, não me visitavam nem me tocavam nem me faziam perguntas, onde me deixavam em paz [...]". (ANTUNES, s/d, p.349).
} 
deixado o amante e de ser procurada por Francisco, que insiste em implorar a sua volta: "Não adianta chorar Francisco não chores eu estou bem palavra que estou bem não te preocupes não vou voltar contigo não insistas não me digas nada não adianta chorar [...] (idem, p.315). Tal rejeição nunca foi superada por Francisco: "quando a Isabel me trocou por outro" (idem, p. 354), que depois de convencer uma outra mulher a se vestir e se portar como Isabel ${ }^{7}$, desabafa: “- A pessoa que me fazes lembrar também nunca me teve amor" (idem, p.310).

A narrativa em primeira pessoa tem caráter confessional: o protagonista narrador é levado a narrar catarticamente o processo transformador pelo qual passou numa tentativa de, através da palavra-narrativa (seu papel ordenador do cosmo - O Logos), tentar entender o que se passou. Em São Bernardo, especificamente, a necessidade de narrar está diretamente vinculada à necessidade de procurar organizar o seu cosmo/ vida para tentar entendê-la. Mas, o autoconhecimento passa pelo conhecimento do outro - da outra - que é/foi a causadora, a motivadora do processo de transformação no qual ele foi projetado. Paulo Honório, por exemplo, ouve o pio da coruja, se lembra

7 Esta atitude de Francisco é uma tentativa de reviver uma época em que era feliz com sua esposa: "entrava num apartamento empoleirado sobre as trevas do parque, que aluguei e decorei e paguei e fazia de conta ser a minha casa como fazia de conta que a mulher que me recebia no capacho e se vestia como a Isabel, se penteava como a Isabel, usava o perfume da Isabel era de facto a Isabel, não a Isabel da altura da separação mas a Isabel do tempo em que nos conhecemos, uma mulher que aluguei e decorei e paguei [...] e eu a afagar a Isabel através daquela a quem chamava Isabel [...]”. (ANTUNES, s/d, p.355). de Madalena e então (como efeito) se põe a escrever suas memórias.

Nos outros dois romances, apesar de múltiplos narradores, há momentos em que os próprios personagens resgatam recordações na tentativa de entender o que se passou. Em $O$ manual dos inquisidores, em que toda a história de Francisco é relatada por outros narradores, é ele que fecha o romance, retomando a figura de sua esposa: "não concebo este nome sempre a voltar-me à ideia, sempre a voltar-me à boca, esta recordação, esta lembrança [...]" (ANTUNES, s/d, p.356), e continua: "a ver se consigo entender-lhe a importância, o sentido [...]" (ibidem).

Em suma, pode-se dizer que Madalena, Clara e Isabel funcionam como o elemento ativador do processo de transformação desses protagonistas. Pois é a impossibilidade de compreendê-las, a impossibilidade de penetrar em suas almas e desvendá-las, querendo dominá-las, sufocando-as, na tentativa de moldá-las às suas maneiras que os coloca em situações de conflitos, conduzindo-os a um drama interior. Se não alcançam a essência das mulheres, não compartilham suas ideias, não se fundem, não tocam seus espíritos, isso para eles se torna insuportável, fazendo-os se sentirem incapazes. Justo eles que, a priori, se quisessem, teriam tudo a sua mão.

Vale lembrar que, se não conseguiram penetrar na intimidade de suas esposas e desvendar seus mistérios, não foi por falta de desejo nem de tentativas - ainda que tentativas ao seu modo -, mas sim por não compreenderem que suas mulheres não 
compartilhavam dos mesmos objetivos, dos mesmos pensamentos, nem tampouco estavam dispostas a mudar seus ideais em prol de uma convivência menos conflituosa. Em consequência disto, cada uma buscou um escape para que assim pudessem conviver com seus maridos. Madalena e Clara, na assistência aos desvalidos, e Isabel se refugiou nos braços de um amante. Clara, por amar seu marido e por viver no seu mundo particular, conseguiu, a seu modo, manter-se por muito mais tempo ao lado de Esteban.

Como dito acima, Paulo Honório, Esteban e Francisco veem suas mulheres como propriedades e tentam de certa forma se apossar de sua alma, do seu pensar, embora em momento algum consigam tê-las por completo, pois estas nutrem visões de mundo diferentes de seus maridos e não se deixam tragar para seu universo de autoritarismo e posse. E, sem elas, as propriedades que até então simbolizavam poder, controle e ordem, deixam de ser o "tudo" para seus proprietários e, assim, São Bernardo, Las Tres Marías e Palmela entram em um processo lento de decadência, até o seu total abandono.

Após a morte de Madalena, Paulo Honório, que até então tinha um alto sentimento de posse, de poder e de domínio sobre todas as coisas e pessoas, perde o ímpeto de adquirir e adquirir. A Revolução de 30 dificulta-lhe os negócios e ele não reage. A propriedade que até então passara por inúmeras melhorias, independente de qual fosse o sistema, torna-se decadente dia após dia e seu dono não faz absolutamente nada.

Para Esteban, a morte de Clara significou o fim de uma Era em que havia brilho em sua vida, mesmo que nunca tivesse percebido plenamente isto: "La muerte de Clara transtornó por completo la vida de la gran casa de la esquina. Los tiempos cambiaron. Con ella se fueron los espíritus, los huéspedes y aquella luminosa alegría que estaba siempre presente [...] (ALLENDE, 2001, p. 310). E este brilho natural que Clara possuía funcionava como uma espécie de energia para todos e tudo que estivesse ao seu redor, tanto que: "En el transcurso de los años siguientes la casa convertió en una ruina” (idem, p.311). E assim como sua propriedade, após a morte de Clara, o senador Trueba também vê seu mundo desmoronar.

O mesmo ocorre com a quinta Palmela, cuja ruína é possível visualizar já no parágrafo inicial do livro: "as estátuas do jardim quebradas, a piscina vazia, o capim que devorava os canis e destroçara os canteiros, a grande casa destelhada onde chovia no piano [...]" (ANTUNES, s/d, p.1). E também com Francisco:

[...] o meu pai mais solitário do que em toda a vida o conheci, sem mulher, sem amigos, sem subordinados, sem cúmplices, afastando à coronhada as vacas do estábulo na ideia de procurar revolucionários nas manjedouras, nas bilhas de leite, nos sacos de sementes, na palha [...]. (idem, p.10).

Outra semelhança entre os três romances é que, após a saída das mulheres da vida destes protagonistas, ocorrem revoluções políticas que foram determinantes para mudanças no poder e consequentemente mudanças em torno desses personagens, o que viria naturalmente a comprometer 
também seus negócios. Em São Bernardo e em O manual dos inquisidores é o golpe militar que vem derrubar o sistema vigente. Naquele, o golpe que instalaria Getúlio Vargas no poder, dando fim à República Velha e inaugurando uma nova política econômica, o que viria a afetar diretamente os grandes latifúndios. E neste, um golpe militar disposto a substituir o anterior, determinando assim mudanças de mando. Em La casa de los espíritus é o governo popular que vence as eleições, o que causa um grande choque para a oligarquia que comandava o país por décadas. Todavia, este governo não perdura por muito tempo, pois a mesma oligarquia que sofreu derrota nessas eleições conspira e financia um novo golpe militar.

Até essas revoluções, o poder se mantinha estável. Uma porção pequena de mandatários mantinha em rédeas curtas a grande maioria de subservientes. Nos dois primeiros romances percebe-se que a mão de obra era explorada e não se podia conceber que os camponeses tivessem sequer alguma pretensão de direito. No caso de São Bernardo, a preocupação com o lado humano dos trabalhadores é praticamente nula, e Paulo Honório não tinha nenhuma intenção de despertar neles qualquer desejo individual que afetasse o coletivo, pois, segundo ele tudo estava em seu devido lugar: "os pretos não sabiam que eram pretos, e os brancos não sabiam que eram brancos" (RAMOS, 1983, p.36). Ou seja, independente da raça, pobre era igual a pobre e nada mais. Esta distinção de raça por parte de Paulo Honório também está em $O$ manual dos inquisidores, mas de maneira mais preconceituosa em relação à raça negra mesmo: "[...] se os pretos soubessem o que querem não havia problemas eram brancos" (ANTUNES, s/d, p.106).

Não se pode deixar de dizer que neste romance também os pobres são vistos como animais, porém, não qualquer animal, mas um animal domesticado: "enquanto eu tinha um pobre só para mim", "quando o meu pobre morreu [...]", "e após a morte do meu pobre ofereceram-me um pobre mais novo que durasse mais tempo [...]" (ANTUNES, s/d, p.54).

Em relação ao trato com os seus trabalhadores, Esteban, por sua própria iniciativa, constrói moradia e escola para eles, além de não lhes negar alimentos. $O$ que faz com que ele fique indignado é ter que pagar salário ou distribuir suas terras para os camponeses, pois isso significaria perda da concentração de poder. Além do que, recompensar os camponeses com dinheiro ou terra, no pensamento de Esteban, seria uma grande injustiça para homens como ele, que se tinha o que tinha, era devido a muita determinação e privações.

O tema das revoluções é bastante frequente nos três romances, funcionando mesmo como fator determinante na vida dos personagens. Nenhum deles, enquanto centralizadores de poder, consegue passar por elas sem sentir seu efeito.

Em São Bernardo, os primeiros indícios de que algo iria mudar são apresentados pelo Padre Silvestre tido como "danadamente liberal", oposicionista do governo e que achava "que os políticos, individualmente, são criaturas como as outras, mas 
em conjunto são uns malfeitores" (idem, p.127). Para o Padre, a mudança de mando do país estaria prestes a acontecer: "A facção dominante está caindo de podre. $O$ país naufraga, seu doutor. É o que lhe digo; o país naufraga" (ibidem). E prenuncia: "Há de haver uma revolução!” (ibidem). Porém a revolução pretendida pelo Padre não tem nada a ver com o comunismo: "Essas doutrinas exóticas não se adaptam entre nós. O comunismo é a miséria, a desorganização da sociedade, a fome" (idem, p.128).

E um dia, como o Padre dissera, a revolução acontece: "Um dia Azevedo Gondim trouxe boatos de revolução. O sul revoltado, o centro revoltado, o nordeste revoltado" (RAMOS, 1983, p.173). A síntese deste movimento é assim descrito:

Depois os boatos engrossaram e viraram fatos: batalhões aderindo, regimentos aderindo, colunas organizando-se e deslocando-se rapidamente, bandeiras encarnadas por toda a parte, o governo da República encurralado no Rio. (RAMOS, 1983, p.173).

Em pouco tempo "a onda vermelha inundou o Estado" (ibidem), e os "Figurões do governo apareceram de repente com lenços vermelhos no pescoço" (idem, p.175). Passado o momento de euforia por parte dos vitoriosos, os bancos cessaram os empréstimos, compradores quebraram, começam as falências e o desaparecimento das plantações, o dólar sofre alta e, por fim, muitos suicídios.

Para aqueles que viviam de outro modo que não fosse o da terra ou comercialização de produtos, as novas medidas do governo não os afetaria diretamente. Assim Nogueira, advogado de Paulo Honório, opina sobre o que estava ocorrendo e sua situação particular dentro desse novo panorama político:

[...] tanto me faz estar em cima como embaixo, que política nunca me rendeu nada. Estou embaixo e não pretendo subir. É verdade que sempre achei a democracia um contra-senso. Muitas vezes lhe disse. O diabo é que votei na chapa do governo. Mas aqui entre nós a ditadura só não presta porque estamos no chão. (RAMOS, 1983, p.175).

Em La casa da los espíritus, o personagem Esteban, além de grande latifundiário, é senador pelo partido da situação. Como seu partido mandava no país há décadas, não lhe passava pela cabeça que pudesse haver outro resultado que não fosse uma vitória para os seus: "Ganaremos los de siempre" (ALLENDE, 2001, p.357). Por isso, quando o candidato da oposição vence as eleições, ele, como interessado direto pelos resultados, lamenta amargamente a derrota. Derrota esta sentida por toda a classe favorável à situação: "Los de siempre, acostumbrados al poder desde tiempos inmemoriales [...]" (ibidem).

Os trechos abaixo resumem o que foi para o povo aquele momento de sensação de libertação do regime há muito estabelecido, bem como a frustração da burguesia derrotada:

En las señoriales residencias blancas, azules y amarillas del Barrio Alto, comenzaron a cerrar las persianas, a trancar las puertas y a retirar apresuradamente las banderas y los retratos de su candidato, que se habían 
anticipado a poner en los balcones. Entretanto, de las poblaciones marginales y de los barrios obreros salieron a la calle familias enteras, padres, niños, abuelos, con su ropa de domingo, marchando alegremente en dirección al centro. [...] En el Barrio Alto, algunos estudiantes, inflamados de idealismo, hicieron una morisqueta a sus parientes congregados alrededor del televisor con expresión fúnebre, y se volcaron también a la calle. De los cordones industriales llegaron los trabajadores en ordenadas columnas, con los puños en alto, cantando los versos de la campaña. En el centro se juntaron todos, gritando como un solo hombre que el pueblo unido jamás será vencido. (ALLENDE, 2001, p.358). [...]

[...] $\mathrm{Y}$ entonces se vio el inusitado espectáculo de la gente del pueblo, hombres con sus zapatones de la fábrica, mujeres con sus hijos en los brazos, estudiantes en mangas de camisa, paseando tranquilamente por la zona reservada y preciosa donde muy pocas veces habían aventurado y donde eran extranjeros. (ibidem). [...] Aldía siguiente, los mismos que habían pasado la noche en vela aterrorizados en sus casas salieron como una avalancha enloquecida y tomaron por asalto los bancos, exigiendo que les entregaran su dinero. Los que tenían algo valioso, preferían guardarlo debajo del colchón o enviarlo al extranjero. (idem, p.359).

Como era de se esperar, logo após o resultado das eleições o país já começava a sentir seus efeitos: "En veinticuatro horas, el valor de la propiedad disminuyó a menos de la mitad" (idem, p.359), e: "En pocas horas el país se dividió en dos bandos irreconciliables y la división comenzó a extenderse entre todas las familias" (idem, p.359-360).

Posteriormente, com o novo governo, uma série de novas medidas começou a ser implantada, entre elas, a reforma agrária:

Las Tres Marías fue uno de los últimos fundos que expropió la Reforma Agraria en el Sur. Los mismos campesinos que habían nacido y trabajado por generaciones en esa tierra, formaron una cooperativa $y$ se adueñaron de la propiedad. (idem, p.373).

Todavia, esta mesma classe que amargou derrota e que viu seus negócios serem afetados violentamente pelo governo popular, não se dá por vencida e planeja um golpe militar: "-Una cosa es ganar la elección y otra muy distinta es ser Presidente [...]. (idem, p.360). E assim se dá: "El día del golpe militar amaneció con un sol radiante, poco usual en la tímida primavera que despuntaba. (idem, p. 385). Os militares tomam o poder, matam o presidente e começam uma caçada ferrenha aos oposicionistas: "La alta burguesía y la derecha económica, que habían propiciado el cuartelazo, estaban eufóricas" (idem, p.403).

Para Esteban tudo estaria bem depois deste êxito, pois para ele a ordem havia sido restabelecida. Mas, a morte do seu filho Jaime, e em seguida a prisão de sua filha Blanca pelos militares, levam o senador a tomar consciência de que, se um governo populista não seria o ideal para seu país, tampouco o novo regime instalado que financiara seria a melhor saída: "Empecé a pensar que me había equivocado en el 
procedimiento y que tal vez no era esa la mejor solución para derrocar al marxismo" (idem, p.396).

Esta tomada de consciência não ocorre em Francisco que, passado tempos após a revolução, continua com a mesma ideologia de antes e detestando os "comunistas". Não é para menos. O golpe, para ele, afeta diretamente a sua pessoa, pois seu posto de ministro era uma das estruturas do regime salazarista, era em sua quinta que Salazar costumava discutir o governo do país. Portanto, a queda deste governo, visto como "a última barreira contra o comunismo ateu" (ANTUNES, s/d, p.106) que soprava do oriente, será inevitavelmente a sua queda enquanto representante do seu cargo, enquanto figura do poder e enquanto indivíduo.

Do mesmo modo que a revolução abala a posição de Francisco, assim ela é sentida pelos membros da classe alta, simpatizantes da causa da situação:

[...] soldados marchas militares armas prisões a minha sogra e as cunhadas em Espanha em hotéis de terceira ordem nos arredores de Madrid sem malas de viagem sem passaporte apavoradas tentando ligar para Lisboa sem que lhes respondessem tentando ligar para a herdade e os camponeses a insultarem-nas aos berros a minha sogra e as cunhadas em Espanha com vários casacos de peles uns por cima dos outros com vários relógios de ouro em cada pulso e os irmão da minha sogra humilhados por civis de pistola [...]. (ANTUNES, s/d, p.09).

O interessante neste romance é que passados os primeiros momentos de caça às bruxas, a classe alta volta a usufruir dos mesmos privilégios e a classe desfavorecida permanece na mesma situação de outrora, ou seja, na pobreza. Odete, a filha do caseiro assim vê o movimento:

os operários da fábrica que discursavam na rua a tratarem-nos por camaradas, a prometerem-nos casas de graça, a afirmarem que éramos livres e eu pensei - Livres de quê? já que a miséria permanecia a mesma [...]. (ANTUNES, s/d, p.25).

[...] a vida continuava como antes dos foguetes, dos morteiros, do acordeão do café e dos discursos sobre casas de graça e liberdade [...]. (idem, p.25).

Mas, para Francisco nada continuou como antes. Sem esposa, sem cargo e ciente da sua condição: "já não há nada que me possam levar" (idem, p.32), confundindo os seus funcionários da quinta com aqueles que haviam tomado o poder, ele expulsa todos e passa a viver na mais repleta solidão. Um ano depois da revolução ainda esperava os comunistas: "-O primeiro comunista que se atrever a entrar leva um tiro nos cornos" (idem, p.10). Passado o tempo, é internado em um asilo e já não lembra mais o homem poderoso que fora um dia:

o meu pai de queixo pendente, de nádegas bambas, a tentar limpar o nariz com a manga que treme [...] o meu pai calado, submisso, inútil, sem cigarrilha, sem dentadura postiça, sem lábios, sem chapéu estendido no colchão, como um espantalho de cama [...]. (ANTUNES, s/d, p.33). 
Assim terminam os personagens aqui resgatados, velhos, solitários em sua caminhada final, delirando e chamando pelo nome de suas mulheres. Três homens que chegaram ao auge do poder, bem simbolizado na magnitude de suas propriedades, mas que, condicionados por este poder, foram incapazes de vivenciar as mais simples experiências humanas acerca de sentimentos. Três homens entre o poder e suas mulheres, e com um mesmo fim - decadentes, imersos em seus próprios fantasmas - com a culpa, o sentimento de perda e totalmente fragilizados. Apenas sombras do que foram um dia.

Entendendo que a literatura é uma reorganização do mundo, segundo Antonio Candido (1973), e que ninguém faz um discurso sem conhecer a realidade dos fatos, conforme Norberto Bobbio (1997), não podemos deixar de associar a questão social, as mazelas da classe dominante e a coisificação do homem, retratadas nestes romances, com a realidade conflituosa que permeou o século XX e, consequentemente, com a percepção dos autores destas obras em relação a essa realidade.

Bobbio (1997) diz que o problema não é saber se os intelectuais são rebeldes ou conformistas, livres ou servis, independentes ou dependentes, mas sim o que estes, ao se reconhecerem em uma determinada parte política, fariam ou deveriam fazer. Avaliar se os autores, nas obras aqui citadas, fizeram o que deveriam fazer, é assunto para outro trabalho.

\section{REFERÊNCIAS}

ALLENDE, Isabel. La casa de los espíritus. Buenos Aires: Editorial Sudamericana, 2001. ANTUNES, António Lobo. o manual dos inquisidores. Lisboa: Publicações Dom Quixote, s/d.

BAKHTIN, Mikhail. Estética da criação verbal. São Paulo: Martins Fontes, 1997.

BENJAMIN, Walter. Magia e técnica, arte e política: ensaios sobre literatura e história da cultura. 7.ed. São Paulo: Brasiliense, 1994.

BOBBIO, Norberto. Os intelectuais e o poder: dúvidas e opções dos homens de cultura na sociedade contemporânea. São Paulo: Editora da UNESP, 1997.

CANDIDO, Antonio. Literatura e sociedade: estudos de teoria e história literária. São Paulo: Companhia Editora Nacional, 1973.

FELDMANN, Helmut. Graciliano Ramos: reflexos de sua personalidade na obra. 2. ed. Fortaleza: Imprensa Universitária do Ceará, 1998.

LAFETÁ, João Luís. O mundo à revelia. In: RAMOS, Graciliano Ramos. São Bernardo. Rio de Janeiro: Record, 1983.

RAMOS, Graciliano. São Bernardo. 40.ed. Rio de Janeiro: Record, 1983.

SARTRE, Jean-Paul. Em defesa dos intelectuais. São Paulo: Ática, 1994.

SELIGMANN-SILVA, Márcio. O local da diferença: ensaios sobre memória, arte, literatura e tradução. São Paulo: Editora 34, 2005.

Recebido para publicação em 01 set. 2010. Aceito para publicação em 19 jan. 2012. 